\title{
Investigation of Electrochemical Behavior of Mordant Dye (C.I. 17135)
}

\author{
Serpil Zeyrekli ${ }^{1}$,Yeliz Karaman ${ }^{2}$ and Necati Menek ${ }^{1, *}$ \\ ${ }^{1}$ Ondokuz Mayis University, Sciences and Arts Faculty, Department of Chemistry, 55139, Kurupelit- \\ Samsun, Turkey \\ ${ }^{2}$ Sinop University, Sciences and Arts Faculty, Department of Chemistry, 57000, Sinop, Turkey \\ *E-mail: nmenek@omu.edu.tr
}

doi: $10.20964 / 2021.05 .61$

Received: 16 January 2021 / Accepted: 10 March 2021 / Published: 31 March 2021

\begin{abstract}
In this study, the electrochemical behavior of Mordant dye (C.I. 17135) was investigated in BrittonRobinson (BR) buffer ( $\mathrm{pH}$ 2.0-12.0) media by using different techniques, which are square wave voltammetry (SWV), cyclic voltammetry (CV), differential pulse polarography (DPP), direct current polarography (DCP) techniques. The polarograms and voltammograms of the dye on a static mercury drop electrode (SMDE) and hanging mercury drop electrode (HMDE) show one reduction peak corresponding to the two-step four electron electrode reaction mechanism. In SW voltammograms and DP polarograms of the dye, a broad shoulder peak was seen in the $\mathrm{pH}$ range of 2.0 to 12.0 , due to the adsorption of the azo dye on the electrode surface. The shift of the peak potentials to more negative values indicate that the protons are involved in the electrode reaction. The effect of scan rate on the reduction peak has been studied at different $\mathrm{pH}$ values.
\end{abstract}

Keywords: Mordant dye, reduction, scan rate, reaction mechanism.

\section{$\underline{\text { FULL TEXT }}$}

(C) 2021 The Authors. Published by ESG (www.electrochemsci.org). This article is an open access article distributed under the terms and conditions of the Creative Commons Attribution license (http://creativecommons.org/licenses/by/4.0/). 